\title{
Aspergillus sydowii ISOLATED FROM TWO BRONCHIAL LAVAGE SAMPLES
}

\section{( Aspergillus sydowii aislado de dos muestras de lavado bronquial)}

\author{
*Oliane Maria Correia Magalhaes, Lusinete Aciole de Queiroz, \\ Maria José Fernandes, Cristina Maria de Souza., **Laura Torres. \\ *Mycology Department, Centre of Bilogical Sciences, Federal University of \\ Pernambuco, 50670-420, Recife, PE, Brasil. \\ ** Otávio de Freitas General Hospital, Recife, PE, Brasil.
}

Palabras clave: Aspergillus sydowii, lavado bronquial. Key words: Aspergillus sydowii, bronquial lavage.

\section{RESUMEN}

Se analizaron 2 muestras de lavado bronquial de un paciente hospitalisado en la Unidad de Penumologia del Hospital General Otávio de Freitas, Recife, PE, Brasil. El exámen directo en ambas muestras reveló la presencia de:conidios redondos pequeños (aislados y agrupados), hialinos. En la segunda muestra se observaron paralelamente células de levaduras, ovales, oblongas y gemantes. Se obtuvieron en ambas muestras, cultivos puros de Aspergillus sydowii y Candida albicans.

\section{INTRODUCTION}

Pulmonary aspergillosis is an opportunist disease, frequently occurring as a result of pre-existing lesions as in other etiologies. It presents distinct clinical forms, such as allergic bronchopulmonary, invasive and intracavitary (fungal ball or aspergilloma); the most commonly found etiological agents are the species Aspergillus fumigatus, A. flavus and A. niger (Conant et al., 1971; Rippon, 1982; Wanke, 1984; Lacaz et al.. 1991).

According to Wanke (1982) in Brazil this mycosis has not been the subject of much study and it is seldom diagnosed.

Various studies show that there may be an association of pulmonary aspergillosis and pulmonary tuberculosis (Butzet al., 1985; Morozov et al., 1989; Gaeta et al., 1992) and the occurrence of post tuberculosis aspergilosis has been referred to by various authors (Gonzales et al., 1985; Stamatis \& Greschuchna, 1988; Kreisel et al., 1990; ; Kohno et al., 1992; Maesaki et al., 1993; Wex et al., 1993).

Neoplasic processes bring in their wake alterations

\section{SUMMARY}

Two samples of bronquial lavage of a patientt hospitalized in the Pneumologv Unit of the Otavio de Freitas General Hospital, Recife, PE, Brazil were tested. The direct examination of the two samples revealed the presence of small round hialine conidia (isolated and grouped); in the second sample, apart from these findings, the presence of oval and oblong yeast cells with simple budding was determined. The pure cultures of Aspergillus obtained from the two samples of bronchial lavage were identified as A. sydowii and pure cultures of Candida were identified with $C$. albicans.

in the hosts which favour opportunist fungal infections, amongst which are those caused by the species $A$ spergillus (Ferreira et al., 1983; Gefter et al., 1985; Salerno et al., 1986; Vidotto et al., 1986; Stokes et al., 1989., Pizzo \& Walsh, 1990; Grillot et al., 1991; Smith \& Beneck, 1991; Elias et al., 1993).

This paper has as the only objectives to detect, isolate and identify fungi of the respiratory systems of patients hospitalized in this hospital.

\section{MATERIALS AND METHODS}

Two samples of bronchial lavage, collected 3 months apart, were processed from a 39 year old, male patient, a native of Recife, hospitalized in the Pneumology Unit of the Otavio de Freitas (SANCHO) General Hospital, who had been diagnosed with diabetes mellitus and pulmonary tuberculosis with a non-realized resistant Bacillus-alcohol-acid (BAAR), with negative histopathological neoplasic cells, and positive for filamentous 
fungi. The two samples of bronchial lavage were obtained and supplied by bronchoscopy and had been sent to the Mycology Department where they were duly processed for direct examination and culture. The time between collection and manipulation of the clinical samples did not exceed 2 hours.

The direct examination of the bronchial lavage samples was undertaken on their native state (without colouring or clarifier).

The 2 samples of bronchial lavage were seeded in duplicate in Petri dishes with Sabouraud agar plus 0.5\% of yeast extract (YE) and $50 \mathrm{mg}$ of chlorophenicol $/ 1$, and incubated at room temperature (RT) $28-29^{\circ} \mathrm{C}$ and $37^{\circ} \mathrm{C}$.

The cultures which arose after being purified were maintained in the above-mentioned means of culture without antibiotics and held in a test tube.

For identification and classification Raper \& Fennel (1965) were consulted for the Aspergillus strains as well Kreger-van Rij (1984) and Barnett et al. (1990) for the yeast strain.

\section{RESULTS}

The direct examination of the 2 bronchial lavage samples revealed the presence of small, round hialine conidia, isolated and grouped; in the second sample, apart from the spores already mentioned, the presence of oval and oblong yeast cells with simple budding was noted.

The Aspergillus pure cultures obtained from the 2 samples of bronchial lavage in Sabouraud agar $+\mathrm{YE}+$ chlorophenicol, both at RT and $37^{\circ} \mathrm{C}$, were identified in Czapec and Malt agar as $\boldsymbol{A}$. sydowii. After being purified, the Candida cultures obtained from the second sample of bronchial lavage were identified as $C$. albicans.

The 2 samples of $\boldsymbol{A}$. sydowii ( 3631 and 3632) and C. albicans (3620) are deposited in the URM-Mycotheca of the Mycology Department, Centre of Biological
Sciences, Federal University of Pernambuco, Recife, PE, Brazil.

\section{DISCUSSION}

In the literature the association between pulmonary aspergilosis and pulmonary tuberculosis was reported by Tomlinson \& Steven (1987), and Kumar et al. (1992) and with diabetes mellitus by Karen et al. (1988).

Through clinical, histopathological and serological examinations, as well as mycological examination of the sputum and bronchial secretion, pulmonary aspergilosis cases were diagnosed which have the species $A$. fumigatus, A. niger and A. flavus ( Tomlinson \& Steven , 1987; Kumar et al., 1992) as etiological agents. Bandele et al. (1993), however consider the presence of $\boldsymbol{A}$. fumigatus, $\boldsymbol{A}$. niger and Aspergillus sp. in the sputum of patients as pulmonary tuberculosis as an infection and not as pulmonary aspergillosis. The results obtained in this work showed the presence of $\boldsymbol{A}$. sydowii (Section Versicolores) (W. Gams et al. 1985) in the bronquial lavage samples.

The fungus $A$. sydowii was isolated from clinical samples of hands and ulcer (Raper \& Fennel, 1965). As a saprophic it has been isolated from the soil, vegetables, bird excrement and foodstuffs (Raper \& Fennel, 1965; Domsch et al., 1980; Pitt \& Hocking, 1985).

There is no reference in the literature about the occurrence of $\boldsymbol{A}$. sydowii in respiratory systems samples

Thus we can conclude that $\boldsymbol{A}$. sydowii is being mentioned for the first time as a fungi present in bronquial lavage samples detected from direct and culture examination.

It was not possible to get further clinical data on this case so we focused merely on this interesting isolation without considering possible derived pulmonary aspergillosis.

\section{REFERENCES}

Bandele, e. O.; Odubgemi, T.; Nwobv, R. A. V. (1993). Fungal chist infections at the Lagos University Teaching Hospital. East African Medical Journal 70: 146-150

Barnett, J. A.; Payne, R. W.; Yarrow, D. (1990). Yeasts. characteristics and identification. Cambridge University Press, Cambridge $1002 \mathrm{pp}$.

Butz, R. O.; Zvetina, J. R.; Lèininger, B. J. (1985). Ten-year experience with mycetomas in patients with pulmonary tuberculosis. Chest 87: 356358

Conant, N. F.; Smith, D. T.; Baker, R. D.; Callaway, J. L. (1971). Micologia. Interamericana, México, 592pp.

Domsch, K H.; Gams, W.; Anderson, T. H. (1980). Compendium of soil funqi. Academic Press, London, $859 \mathrm{pp}$.
Elias, A. D.; Ayash, L. ; Frei, E. III. ; Skarin, A. T.; Hunt, M.; Wheeler, C.; Schwartz, G. ; Mazanet, R. ; Tepler, I. ; Eder, J. P.; McCauley,M. ; Herman, T.; Sclunipper, L. ; Antaman, K. H. (1993). Intensive combined modality therapy for limited-stage smallcell lung cancer. J. Natl. Cancer Inst 85: 559-566

Ferreira, A. F.; Carneiro, P. C.; Barbosa, J. A.; Pozzi, D. H.(1983). Aspergilose pulmonar, aspectos anatomo-patológicos de um paciente portador de leucemia linfóide aguda. Hosp. Clin. Fac. Med. Univ. São Paulo 38: $267-268$

Gaeta, M. ; Volta, S. ; Stroscio, S. ; Pandolfo, I. (1992). CT "halo sign" in pulmonares tuberculoma. Journal of Compater Assisted Tomography 16: 827-828

Gams, W.; Christensen, M.; Onoons, A.II.; Pitt, J.I.; Samson, R. A. 
(1985). Infrageneric taxa of Aspergillus. In: Advances in Penicillium and Aspergillus Systematics (Eds. R. A. Samson \& J. I. Pitt), 55-62 pp. New York: Plenum Press.

Gefter, W. B.; Albelda, S.M.; Talbot, G.H.; Gerson, S.L.; Cassi Leth, P.A.; Miller, W. T. (1985). Invasive pulmonary aspergilosis and acute lenkemia: Limitation in the diagnostic utility of the air crescent sign. Radiology 157: 604-610

Gonzales, R. C. ; Rodrigues, E. A. ; Rodrigues, C. H. (1985) Aspergillosis pulmonary. Rev. Argent. Cir. 48: 135-137

Grillot, R. ; Lebean, B. ; Pinel, C. ; Fricker, H. ; Ambroise-Thomas, P. (1991). Biological diagnosis of systemic mycoses in patients with cancer. J. Mycol-Med. 4-10.

Kohno, S. ; Hatano, C.; Yamada, H.; Maesaki, S.; Yasuoka, A.; Kaku, M. ; Koga, H., Hara, K. (1992). Superinfeetion of chronic necrotizing pulmonary aspergillosis by Mycobacterium tuberculosis. Intern. Med 31: $540-543$

Kreger - van Rij, N. J. W. (1984). The Yeasts: a taxonomie study. Elsevier Sci. Publi., Amsterdam, 1091 pp.

Kreisel, W.; Kochling, G.; Von-Schilling, C.; Azemar, M.; Kurzweil, B.; Dolken, G.; Lindemann, .A.; Blum, U. ; Windfuhr, M. ; Muller, J. (1990). Therapy of invasive aspergillosis with itraconazole: improvement of therapeutie efficacy by early diagnosis. Mycoses 10 : 385- 394

Kumar, S.; Kumar, R.; Saini, S. ; Sobherwal, U. ; Arora, D. R. (1992). In eidenee of mycoses in bronchopulmonary disorders. Indian J. Pathol. Microbiol, 35: 237-240

Lacaz, C. da S. ; Porto, E. ; Martins, J. E. C. (1991). Micoloqia Médica: fungos, actinomycetes e algas de interesse médico. Sarvier,.São Paulo. 479pp.

Maesaki, S.; Kohno, S.; Tanaka, K.; Miyazaki, H.; Mitsutake, K.; Miyazaki, T.; Tomono, K.; Kaku, M.; Koga, H.; Hara, K. (1993). A case of pulmonary aspergilloma successfully treated with combination therapy of intracavitory infection of amphotericin B and intravenous administration of urinastatin. Nippon. Kyobu. Shikkan. Gakkai. Zasshi., 31: 1327-1331

Morozov, V. L.; Al-Dzhambaeva-I, S. H.; Adambekov, D. A. (1989). Immunogical diagnosis of aspergilosis in patients with pulmonary tuberculosis. Problemy Tuberkuleza 9: 35-38
Pitt, J . I. \& Hocking, A.D. (1985). Fungi and food spoilage. Academic Press. Australia. 16 pp.

Pizzo, P. A.; Walsh, T. J. (1990). Fungal infection in the pediatric cancer patient. Semin. Oncol 17:6-9

Raper, K. B.; Fennell, D. I. (1965). The Genus Asperqillus. Robert E. Krieger Publishing Company Malabar, Florida 686pp.

Rippon, J. W. (1982). Medical Mycology: the pathogenic fungi and the pathogenic actinomycetes. Copyright, Canada. 842 pp.

Salerno, R. A. ; Carvani, A. ; Ezcurra, M. C. ; Elias, A.; Tello, A. L.; Gomez, O.; Colombini, A.; Klimovski,J.; Parise, A. (1986). Colonization and infection in leukemic patients: analysis of 195 surveillance cultures. Medicina (B. Aires) $\quad$ 46: 369-376

Smith, F. B.; Beneck, D. (1991). Localized Aspergillus infestation in primary lung carcinoma. Clinical and pathological contrasts with post - tuberculous intracavitary aspergilloma. Chest 100: 554-556

Stamatis, G. ; Greschuchna, D. (1988). Surgery for pulmonary aspergilloma and pleural aspergillosis. Thorac. Cardiovasc Surg. 36: 356360

Stokes, D. C.; Shenep, J. L.; Parham, D. ; Bozeman, P. M.; Marienchek, W.; Mackert, P. W. (1989). Role of flexible bronchoscopy in the diagnosis of pulmonary infiltrates in pediatric patients with cancer. J. Pediatr $115: 561-567$

Tomlinson, J. R.; Steven, A. S. (1987). Aspergilloma in sarcoid and tuberculosis. Chest 93: 505-508

Vidotto, V.; Clerico, M. ; Franzin, L. ; Lucchini, L. ; Sinicco, A. (1986). Fungal colonization in patients with cancer of the upper respiratory tract. Mycopathologia 96:97-101

Wanke, B. (1984). Micoses pulmonares. Ars. Curandi. 71-85.

Wex, P. ; Utta, E. ; Drozdz, W. (1993). Surgical treatment of pulmonary and pleurp-pulmonary Aspergillus diseases. Thorac.Cardiovasc. Surg. 41:64-70 